\title{
Seeing red? The agency of computer software in the production and management of students' school absences
}

\author{
Linnea Bodén
}

\section{Linköping University Post Print}

\section{Tweet}

N.B.: When citing this work, cite the original article.

This is an electronic version of an article published in:

Linnea Bodén, Seeing red? The agency of computer software in the production and management of students' school absences, 2013, QSE. International journal of qualitative studies in education, (26), 9, 1117-1131.

QSE. International journal of qualitative studies in education is available online at informaworldTM:

http://dx.doi.org/10.1080/09518398.2013.816887

Copyright: Taylor \& Francis (Routledge): SSH Titles http://www.routledge.com/

Postprint available at: Linköping University Electronic Press http://urn.kb.se/resolve?urn=urn:nbn:se:liu:diva-98042 


\section{Seeing red? The agency of computer software in the production and management of students' school absences}

\section{Linnea Bodén}

Department of Social and Welfare Studies, Linköping University, Norrköping, Sweden

Correspondence to Linnea Bodén, Department of Social and Welfare Studies,

Linköping University, Holmentorget 10, SE-60174 Norrköping, Sweden. E-mail:

linnea.boden@liu.se

Linnea Bodén is a Ph.D. student of Educational practice at the Department of Social and Welfare Studies, Linköping University. Her research focuses on school absenteeism and truancy and draws on a feminist relational materialist and posthumanist perspective, with a special interest in technical tools for the registration and control of absence. 


\title{
Seeing red? The agency of computer software in the production and management of students' school absences
}

\author{
An increasing number of Swedish municipalities use digital software to manage \\ the registration of students' school absences. The software is regarded as a \\ problem-solving tool to make registration more efficient, but its effects on the \\ educational setting have been largely neglected. Focusing on an event with two \\ students from a class of eleven-year olds, the aim of the paper is to explore \\ schools' common uses of computer software for registering absence in order to \\ understand how materialities - like the software - are entangled with the \\ production of school absence. In the paper, the Deleuzio-Guattarian concept of \\ the assemblage is put to work within a feminist relational materialist framework. \\ This enables an understanding of the complexity of school absence, where \\ materialities of the educational setting are theorized as entangled with social and \\ gendered discursive components.
}

Keywords: school absence; computer software; feminist relational materialism; assemblage; gender; Deleuze and Guattari

\section{Introduction}

Swedish or Scandinavian schools have often been described as less authoritative than schools in an Anglo-Saxon educational tradition. The Swedish Education Act (SFS 2010:800, Chapter $1,5 \S)$ states that it is the duty of everyone working in schools to promote democratic practices, equality and solidarity. A close and 'friendly' relation between students and teachers, as well as between schools and homes, has been the ideal and regular meetings between teachers, students and guardians is a natural part of the school practice (Erikson 2004; Tallberg-Broman 2013; Wedin 2007. See also OECD 2012). Negotiations and discussions have thus been encouraged, rather than punishments on behalf of the individual student. 
However, it can be claimed that during the last decade a shift has taken place in the Swedish educational discourse: from negotiation and conversation to confrontation and regulation. A conservative-liberal government has held power in Sweden since 2006, and it has placed a strong emphasis on order and control in schools, as reflected in school policies (Larsson, Löfdahl, and Pérez Prieto 2010). This is not a uniquely Swedish tendency, but reflects contemporary transnational trends toward "control societies" and societies of self-management and self-governance (Rose 1999; Sørensen and Triantafillou 2009). The discursive shift to a more authoritative educational setting was manifested in May 2012, when the Swedish government passed a resolution that schools have to report students' unauthorized absences/truancy in report cards for each semester (SFS 2011:506). As an effect of the emphasis on control, the focus on students' absence behaviours has become a central focus for governments worldwide (Reid 2008). The main reason, writes Jonasson (2011), is that absence is regarded as directly related to poor school performance and success or failure in education. Even though the focus on school absence is not unique for Sweden or Scandinavia, it has materialized in a particular way: an increasing number of Swedish municipalities use different forms of digital software to manage the registration of students' school absences ${ }^{1}$. The software is described as an instrument that, when used correctly, will enable "a more professional and efficient management of student documentation" (Stockholms stads utbildningsförvaltning 2011, 2, my translation). According to Sørensen (2009), new technology introduced into the school setting is habitually treated as a 'cure-all' for educational problems, and as a flexible and neutral device for politicians, teachers, or administrators to move education into the next century (Lee

\footnotetext{
${ }^{1}$ Similar systems are used in Finland as well.
} 
2009, 17). The practices and effects the technology brings about are however largely neglected (Sørensen 2009, 1). In response to these statements which are both startling and challenging - especially since more than $80 \%$ of the municipalities in Sweden use digital software for the registration in schools (Bodén 2013) - the aim of the paper is to explore schools' common uses of computer software for registering absences in order to understand how the materialities of the school setting are entangled with the production of school absence.

Within the framework of what has been known as a feminist relational materialist or a post-humanist perspective (Barad 2007; Hekman 2010; Sørensen 2009), Åsberg et al. (2011:220) state that as humans have become closely intertwined with the surrounding technology, notions of the independent human being have become difficult to uphold. When relating this to the control of students' absences in Sweden, it becomes obvious that discourses of the autonomous and independent human being are nevertheless still present. A sharp distinction is constructed between, on the one hand, active human agents who are regarded as using the software as a pedagogical instrument to improve educational practice, and on the other hand, the passive computer software that is being used. This human-centered and individualistic notion of school absence is evident in much of the literature on truancy and school absence (Huck 2011; Kearney and Bensaheb 2006; Reid 2006; Sommer 1985; Veenstra et al. 2010). Contrary to this notion, other researchers have shown that school absence is a multifactored problem, emerging in relations between students, families, the culture of the school and the school environment (Claes et al. 2009; Corville-Smith et al. 1998; Southwell 2006). However, as stressed by Sutphen et al. (2010) and Corville-Smith et al. (1998), a large part of the research in this area has been focused on merely one aspect at a time, making the complexity of school absence difficult to address. 
With reference to a Deleuzian framework, Tamboukou (2008) suggests that in analyzing education it is useful to think of it as "a complex assemblage of interrelations between social structures, economic conditions, power/knowledge relations, architectural and spatial arrangements, forces of desire and pleasure seduction" (369). Thinking about education, and more specifically school absence, as emerging in a complex assemblage (Deleuze and Guattari 1987) is one way of emphasizing its complexity. Bennett (2005) describes an assemblage as a historical and circumstantial grouping of heterogeneous components consisting of both "humans and nonhumans; animals, vegetables, and minerals; nature, culture, and technology" (455). The concept offers a tool to understand how the components are intertwined in a multifaceted gathering and signals a refusal to focus singly on the identities of humans, the technologies, or discourses (Currier 2003). Throughout the paper I will put this concept of assemblage to work within a feminist relational materialist framework to try to unfold the forces of the diverse, or even - at first glance - dissociated, components relating to school absence.

\section{Introducing the theoretical perspective and situating the empirical data}

In what has variously been called 'the new materialist' turn, 'posthumanism', 'material feminisms', 'new materialism', 'posthuman material feminism', or - the term that will be used throughout this paper - 'feminist relational materialism' (Alaimo \& Hekman 2008; Åsberg et al. 2012; Barad 2007; Coole and Frost 2010; Dolphijn and van der Tuin 2012; Hird 2009; Hultman and Lenz Taguchi 2010; Lenz Taguchi 2012), humanistic and anthropocentric assumptions in which "the figure of 'Man' ( sic) naturally stands at the center of things" (Badmington 2004:1345) are challenged. Habitual ways of understanding the world are shaken up as questions are raised about how materialities 
can be understood as agentic. When relating this to the questions raised throughout this paper, it becomes necessary to theorize school absence as not only related to students' individualistic abilities or motivations, but to understand how different materialities is part of what constitutes and produces school absences.

What happens in schools is not only due to the pedagogy, authority or styles of teachers, children's motivations and abilities, modes of interactions, planning and structuring of school practices, educational culture, or the societal function of education (Sørensen 2009, 2).

The material world - crowded with technologies, machines, things, animals and so on is understood as an active agential force (Hultman 2011) and the construction of the world emerges in relations in-between humans, discourse and materialities. The 'materialist turn' is thus not a return to a modernistic view on the material reality as outside or independent of different constructions, but rather a theoretical (re)positioning that refuses to privilege the discursive over the material or the material over the discursive (Hekman 2010). The world is still understood as a construction, but not merely as a social construction. It is an onto-epistemological move to include what has been understood as peripheral or of less/no importance in constructions of the world. The social/discursive is understood as intertwined with the material, and any analysis that attempts to reduce the effects of either of these will always be limited (Barad 2007). Consequently, in this paper the focus moves from the individual student to (the effects of) the practices that evolve in the establishment of a particular arrangement of social and material components (Sørensen 2009). The individualistic notion of school absence can be questioned because, as Bennett (2005) puts it, "if one looks closely enough, the productive power behind effects is always a collectivity" (463). 
To enable a discussion of the theoretical as well as methodological effects of putting this perspective to work I will continue with a brief introduction to my empirical data.

\section{Contextualizing the empirical data: A meeting with the students and the software}

The data collection was carried out, between 2010 and 2013, in three Swedish compulsory schools in which computer software was being used to register the students' attendance. The empirics analyzed in this paper are from observations in two fifth-grade classrooms, with 20 and 22 eleven-year-olds respectively. The data consists of field notes, screenshots from the computer software, and interviews with the teacher. Besides performing classroom observations, I asked the teacher and the students about the software and how they used it. Showing me the computer screen, they explained how the software visualized each student's attendance, through displaying the schedule for the current week. Each field on the schedule represented one lesson, and its color indicated whether a student was present or absent. A blue field signaled that the lesson had not yet been registered, a green field that the student was present at the lesson, a yellow field that the student was missing but that the absence was valid, and a red field that the student had been absent and the absence was invalid. However, red not only indicated physical absence from class but also tardiness, leaving the lesson early without valid reason, or neglecting to bring the required school materials (Stockholms stads utbildningsförvaltning 2009).

My taking part in these classroom situations was, as described by Jones et al. (2010, 479), “a continuous struggle against our [my] own tendencies to lapse into realist or objectifying modes of description that see only what is already assumed to be 'there"'. Taking one step back from the introduction to the empirical data - looking at it 
from within a feminist relational materialist perspective - what is at stake is not so much a description of what actually happened, but what can be understood as a process of separating the humans from the nonhumans as well as the data from the researcher. Within the description, with my questions as a support, the students and the teacher are constituted as being in charge of the situation as the computer screen is described as being used to show me matters concerning the registration of school absences. Simultaneously, I, as a researcher, am created as being able to choose what is worth telling and, in a neutral way, describe it. The brief first description of the data as outlined above could be described in terms of 'a touching upon from a distance'. A distance is created between 1) the humans (the students, the teacher and myself); 2) the materialities (the software, the schedule and the colors); and 3) me as a researcher merely describing the event. The event and the empirics are touched upon, but not engaged with. Describing the event within the realm of feminist relation materialism however makes possible an escaping of dualisms such as humans/nonhumans and the empirical data/the researcher. The concept of the assemblage will provide a way to emphasize this mutual entanglement, discussed in the following.

\section{Putting a Deleuzio-Guattarian concept to work within feminist relational materialism}

Dolphijn and van der Tuin (2012) underline how the Deleuzian project of always rejecting and pushing dualisms (such as materialities/discourses) to the limit is one of the basic underpinnings of feminist relational materialism. To enable an understanding of the complexity of school absence, I will engage with the Deleuzio-Guattarian concept of the assemblage. I find the concept a productive way to put the feminist relational materialist theories to work, enabling an understanding of the ways in which materialities and discourses operate and function together. Simultaneously, I believe 
feminist relational materialism - with its focus on the complexity of different becomings and with its emphasize on the productive 'nature' (for lack of a better term) of both matter and discourse - to be a theoretical as well as methodological framework that enables the studying of the assemblage and the emerging components within it. Deleuzio-Guattarian concepts are often put to work or referred to within a feminist relational materialist framework (see for example Åsberg, Hultman and Lee 2012; Dolphijn and van der Tuin 2012; Hultman and Lenz Taguchi 2010; Jackson and Mazzei 2011; Lenz Taguchi 2012) even though they emerge from a different academic tradition (Lenz Taguchi 2012). Therefore I believe the perspectives become productive together, enabling the creation of new understandings within the field of education.

As emphasized by Jackson and Mazzei $(2011,22)$ an “assemblage isn't a thing it is the process of making and unmaking the thing. It is process of arranging, organizing, fitting together." This highlights how the concept always turns the attention to how discourses and materialities, together, operate and connect. The assemblage is always constituted by (and in) connections; in other words, the components are constituted by the multiple connections that constitute the assemblage (Currier 2003). This means that the focus is not on what the different parts in the assemblage mean or represent, but on what the components function with, and with what other things they transmit intensities (Deleuze and Guattari 1987). It is "a multiplicity that necessarily changes as it expands its connections" (Deleuze and Guattari 1987, 8). All assemblages are compositions of desire (Deleuze and Guattari 1987), where desire is addressed as a force that in complex ways flows between - as well as through - humans and nonhumans, assemblages and bodies (Ringrose 2011). Desire is understood as production a productive force that springs from connections and forms the social - rather than as something that is formed or determined by the social (Deleuze and Guattari 1983, 1987; 
Tamboukou 2006). The concept of desire, according to Deleuze and Guattari, does not spring from lack, as a longing for pleasure, a lost object, or a fantasy. Desire emerges in relational encounters, between both human and non-human agents and is always actualized in concrete relations in an assemblage. When this is related to the questions raised within this paper, school absence can be described as an effect of desire within an historical and circumstantial assemblage.

\title{
An engagement with the students and the software
}

In the following I will introduce an episode from the classroom observation that will be the focus for the upcoming analysis.

\begin{abstract}
After one of the lessons, still sitting in the classroom, the teacher showed me one of the student's web pages. The student was sitting next to us. When the teacher opened the web page, the first thing we noticed was that one of the lessons was all red. The student was upset and anxious and told the teacher that no lesson had been missed that day. The teacher said that there must be some kind of a mistake and quietly told me that this student wasn't the kind who truants. The teacher asked what the student had been doing that day and soon they both remembered that this was the day for helping the staff in the school cafeteria. Therefore, the teacher changed the color from red to yellow; that is, from a 'not valid' to 'valid' absence.
\end{abstract}

Following this, the teacher also wanted to show me what the screen looked like for a student that she claimed had been missing a lot of the lessons. The student had already left the classroom. Several fields of red filled the page, indicating both that the student had been absent from class or had been disturbing the lesson in various ways: by talking too loudly, forgetting to bring a pen or a book, wearing a 'hoodie' in class, or leaving the classroom before the lesson was over. The teacher didn't investigate whether the student really had been absent or disruptive on all these occasions, or if the student perhaps, as in the previous case, had been helping some of the school staff.

This event lasted for less than twenty minutes. Nevertheless, I could not stop thinking 
about it. It seemed as if there was something forcing the teacher and the student in the first example to take care of the red field on the screen, whereas none of the red fields were taken care of in the second example. Informed by the theory of the assemblage, I considered that what had enforced the action was not only related to the possibility of affecting what happened on the part of the two students, the teacher or myself, but to the software, the school cafeteria, and the colored fields on the computer screen and, more importantly, to the relations between them. And it is important to consider one major difference between the situations: one of the students was physically present, whereas the other was not. The student's bodily presence and ability to affect the outcome of the report could be regarded as the main reason for the color being changed. Yet, this assumption draws on the notion that the students are autonomous beings, outside or above the materials that surround them. In the upcoming analysis I will try to show that the student got the opportunity to affect the red field fundamentally as a result of connections to the surrounding materials and discourses. The student in the second example, on the other hand, seems to make other connections in the assemblage and was not given the same opportunity to affect the colors of the fields.

\section{School absence as (produced within) an assemblage}

The aim of the upcoming analysis is to follow the components as they operate within the assemblage and to understand how school absence is actualized in this concrete educational setting. For Deleuze and Guattari, what is produced within an assemblage does not begin with an interest in a specific end (Colebrook 2002, 92). Thus, the analysis will not be an unraveling of the interests that might cause the teacher, the students or myself to act in specific ways or to wish for a specific outcome. As opposed to the first introduction to the material, given above, I will try to contest the tendency for dualism by instead starting 'in the middle' of the empirical data together with the 
different components. The forces and flows between two webpages, two students, a teacher and myself (and, as we shall see, much more than this) is what I will accompany. I will focus on the complex and temporary nature of the assemblage to try to understand "whether it works, and how it works and who it works for" (Deleuze 1990, 22 in Jackson and Mazzei 2011, 181).

\section{The first example: from red to yellow}

In the first example, the sole red field immediately caught the teacher's, the student's, and my attention. On the computer screen, with its mainly green, blue, and some yellow fields (along with the grayish background), the brightness of the color red appeared to bring about a bodily reaction that forced our eyes to engage with it. The fact that I, as a researcher, interested in school absence, was sitting next to the student and the teacher made the red field even more striking. We were no longer looking at the red field on the screen, but were enmeshed with it - or became part of the assemblage - as our eyes were drawn to this specific area of the screen.

Understanding the red field from within a representationalist framework - where the red field is a representation of meaning making by the student, the teacher and myself - would not be difficult. In Western culture, red denotes danger or a stop signal (Derefeldt et al. 2004); it signals that something is wrong or forbidden. Red is the color of blood and is often used to evoke fear (Hutchings 2004). The color red produces absence as something that, in this example, both the student and the teacher (and myself) should wish to avoid. Discursive understandings of the color red are transferred into 'facts' about school absence: it is both forbidden and dangerous to miss lessons. In trying to get away from an understanding of the significance of the components involved, it is however important to shift the attention from representation to production: from the singularity of the 'fact' (the red field) to the multiplicity of how 
discourses and materialities together operate to create the red field as a stabilized and unchangeable 'fact' (cf. Haraway 1989). Within an assemblage, the red field has no significance in itself (cf. Currier 2003) and cannot be understood in terms of a representation, but is intertwined with the other components. When trying to follow how these components become related, or bound together (Grosz 1994), the attention has to be extended to include the other forces at play within the assemblage: the teacher who forgot to write a note in the software about the student working in the school cafeteria; the different choices the software offered in filling in the student's 'statistics'; the red color indicating 'missing from class'; the student's, the teacher's and my bodily experience of the red color hitting our eyes; and our discursively informed notions about what this sign denoted within this context. The meaning of the field thus becomes located within a network of both discursive and material components. If the red field as a material component had not been noticed on the computer screen, none of us would have paid attention to the absence. The red color appears to be a material as well as a discursive force - a materialdiscursive (Barad 2007) force, to speak in a feminist relational materialist language - that has a powerful effect on the other components. The red field produces the student as someone who skipped a lesson, not by simply appearing on the screen but as an effect of the connections within the assemblage the red field is a part of. The student can be understood as being produced as a 'truant,' as long as the connections between the student and the red field are strong and stable. As an effect of those connections, the student was missing from class without permission.

To be able to show that no unauthorized absence had been undertaken the connection between the student and the red field had to be dismissed. To show that the red field was showing the wrong thing was not difficult for this student. Even before the student's objections, the teacher suspected an error. The fact that it was a sole red field 
on the page could be an explanation. But the teacher's notions about this student seemed to be a part of the correction as well: she had turned to me and quietly told me that this is not a truant, but a dutiful student. The objections and the teacher's preconceptions can be described as forcing the teacher to look for other components to explain the absence. When the school cafeteria schedule and the rule allowing students to 'skip class' to help the cafeteria staff became part of the assemblage, the red field could be understood in a new way. The teacher was convinced that the student had a reason for being absent from the classroom and changed the field from red to yellow: from a 'not valid' to 'valid' absence. Once the color was changed, the connections in the assemblage could be understood as producing the student no longer as someone who skipped class without permission, but instead as a dutiful student with no illicit absence. The red field thus became something other than a signal of absence; it became a mistake.

New connections in the assemblage, involving the school cafeteria, can be understood as strengthening the fact that it was only one red field on the screen as well as strengthening the teacher's preconceptions about the student, which in turn prompted a questioning of the field. It seems that what is produced in this assemblage is the possibility of the student and the teacher acting, of getting rid of the red field. Nonetheless, new connections are not always produced in the assemblage, as will be discussed in the following.

\section{The second example: a wall of red fields}

The red field(s) on the screen seem to materialize in another way when looking at the student in the second example. The teacher questioned none of the fields and neither did I ask her to develop what she meant when claiming to know about this student's absence history. One way of understanding this is by noting that this student's page was chosen specifically to show what the screen looked like for a student with many 
unauthorized absences. Why would any of us want to change what we saw when this was the underlying purpose of looking at this screen? However, from a feminist relational materialist perspective, the material practices that made us so willingly accept what the screen showed have to be examined. When the materiality of what almost looked like a red wall covering the page became involved in the event, it seemed nearly impossible to question the truth-value of the fields. The red fields reinforced each other and the connections between them constituted each individual red field as well as the wholeness of the assemblage (cf. Currier 2003). Each lesson the student did not attend blended into the others, and the truth-value of every red field (e.g., every missed lesson) became verified by the other red fields surrounding it.

When taking part in the event in the classroom, it did not even occur to me that I could challenge the claims made by the teacher, as the student in the first example had done. Instead, the number of red fields on the screen became a verification for me as well as for the teacher of the accuracy of the notions about the student, and the notions about the student verified that the software was showing the 'truth'. The materiality of the computer screen and the discursively informed understandings of the student can be seen as intertwined and inseparable. The number of red fields became a materialdiscursive verification that made the software hard to question. The red fields were woven together with other components within the assemblage: the student's previous delays measured in minutes and the numbers that showed on the computer screen, the rules that said that time should be rounded up to the nearest five minutes, the student's body wearing jackets or backpacks that were not allowed in the classroom, and the teacher's memories of all the times this student had missed class or arrived late. What had happened was interwoven with what was to come, in a wavelike motion where each new event consists partly of the previous one (cf. Barad 2007). 
The fact that the red fields were so numerous not only made them appear as a natural part of the computer screen, but also as evidence that the student really had been absent from many lessons. For the teacher and myself, the simple visual comparison of these different pieces of data (cf. Tufte 1983) made it easy to draw conclusions about this particular student's absences. It can be claimed that what is produced here is a silence: an unwillingness to question the red fields, an unwillingness to question whether the student had missed each and every lesson as shown on the screen and an unwillingness to act. This silence should not be understood in terms of an external power or an organizing center outside the assemblage forcing the fields together, but as something produced as a consequence of the connections between the components within the assemblage (cf. Colebrook 2002). The connections between the different components in the assemblage appear to be so strong that the assemblage seemed closed or congealed, with little possibility for new connections to be made.

\section{A change of color? Gender as produced and activated within the assemblage}

Studies have shown that there is little or no correlation between gender and the amount of school absence (Jönsson 1990; Skolverket 2008). Yet, within political and mass media discourse, boys are described as more likely to play truant, as part of what has been named a "masculine non-study culture" (Björklund and Sabuni 2008-06-12 [Swedish Minister of Education; Swedish Minister of Gender equality]). The "panic over 'failing boys"” (Ringrose 2007, 474) stands in harsh contrast to what numerous studies have shown on the image of the 'good school girl': the performance of 'girlhood' or femininity is inseparably intertwined with the performance of a wellbehaved educational subjectivity (Skelton 2010; Skelton et al. 2010; Walkerdine 1998; Walkerdine et al. 2001). 
It was a girl who was sitting next to the teacher and myself in the first example, and a boy who was used as an illustration of a truant in the second example. It could be claimed that in this particular situation, gendered discourses on behalf of the boy and the girl might play a part in what became recognised as a reporting mistake and what was recognised as school absence. However - and this is where it gets really interesting - a feminist relation materialist perspective forces us to never take the role of gender for granted. Rather, to be examined is the way gendered notions of school absence become naturalized in the entanglements with other components within the assemblage. What relations and entanglements with the complex - but still ordinary and daily - material practices of the event made gender an important component?

Throughout the event, the girl is treated like a well-behaved student who is concerned (upset and anxious) about her absence and her concern turns out to be correct, when the school cafeteria becomes part of the assemblage. The boy is treated as a performer of a 'too cool for school' mentality together with the materialities surrounding him (his loud voice, the hoodie, the forgotten pens etc.). It could be claimed that the girl and the boy are part of two different assemblages. However, a Deleuzio-Guattarian theorizing opens up a thinking of the students as part of the same assemblage, but in which the forces and the flows of the components seem to have almost the opposite effects for each of them. It is noticeable, as Deleuze and Guattari (1987) write, that the assemblage becomes different with each new component and each new connection. Whether or not gender converges with other components is thus always a question of the forces of the other components within the assemblage. This means that gender becomes a strong force within the assemblage that sometimes - but not always draws other components to it. One red field on the page of a student who is associated with discursively informed notions of the 'good girl' becomes easy to take care of, 
while many red fields on the page of a student associated with a 'masculine non-study culture' can be more or less ignored. Under these particular circumstances gender becomes - rather than is - an important force that affects whether red fields are seen as mistakes or as reflections of the 'truth'.

What should be underlined here is one important aspect of an assemblage: the components do not come together 'automatically'. There are no forces outside the assemblage that enable the connections between the girl and the school cafeteria or disenables similar connections between the boy and other materialities. Instead it could be claimed that an ongoing process of desiring production assembles and connects the components to produce a specific social practice. The desires seem to produce certain 'truths' and practices of handling what is shown on the screen, affecting the two students in different ways. Deleuze and Guattari reject a thinking on what this desire means, or represents, but emphasize that we need to look at how it functions and who it benefits (cf. Jackson and Mazzei 2011, 203). When the materiality of the red field(s) intersect with (gendered) discourses on school absence - in a materialdiscursive gathering - it can be claimed that desire functions to produce the girl as a good student and the boy as a 'truant'. Desire seems to open up the potentialities for the girl to become something else than what the materiality of the software first showed, whereas this does not occur for the boy. Nonetheless, the rupture in the software - the change of color - seems only possible if the girl really acts like the 'good student' she is presumed to be. The components are always tied to each other within the assemblage (Deleuze and Guattari 1987) and the color change can thus be thought of as something that makes the connections between the girl and gendered notions of feminine school subjectivity even stronger. The images and discourses of the good student convinced the girl, as well as the teacher and me, that blue, green, and (maybe) yellow are the only colors allowed 
on the girl's page. This also makes the red field seem more dangerous on her page; it shouts 'stop!', 'danger!' and 'forbidden!'. This means that school absence is not only produced in and through the technology, but also in relation to gendered discourses within the assemblage.

The desires within the assemblage seem to enable a willingness to act - a social practice of challenging what is seen on the girl's page by changing the field from red to yellow - and at the same time a social practice of silence - of not questioning but trusting what is shown on the boy's screen.

\section{Seeing red?}

To be able to embrace the complexity of school absence, as requested by researchers such as Sutphen et al. (2010) and Corville-Smith et al. (1998), I believe that questions ought to be asked that enable a shaking up of the habitual and that open up something new. In this concluding section I want to examine a question that has influenced my interest in the digital registration of students' school absences: could it be the case that practices of handling school absence become affected by the use of the software?

As schools have become sites where economic, political, and social issues are manifested, students, educators, and schools are managed, monitored, compared, and held responsible in relation to educational as well as societal and economic growth (Youdell 2011). The transnational trend to make education more efficient and controllable has manifested itself in a stricter control over school attendance and an urge to lower the absence rates in Swedish schools. A school with low absence rates is viewed as being more likely to contribute to improved educational results (Jonasson 2011). Consequently, and in relation to the software for registering school absence, the schools with the fewest red fields on their screens could be understood as superior to those with more red fields. Theorizing this from within a feminist relation materialist 
perspective, it can be claimed that the wish to attain control and efficiency plugs into the assemblage and makes each red field appear as a problem not only for the individual student, but also for the teachers and the school. It becomes the school's and the teachers' duty to make sure that lesson reports contain as few red fields as possible. But it also becomes the teachers' duty to connect to the software and to report students' absences/presences for each lesson. Otherwise, the software will show a blue field (lesson not yet registered by teacher), indicating that the teachers have not fulfilled their duty. It can thus be claimed that the new technology in the classroom connects itself to, as well as produces, new forms of self-management, not so much for the students but for the teachers and the school. The technology is a mechanism that governs both the subjects of control (the students) and the controlling authorities (the teachers and the school), a phenomenon thoroughly discussed by Foucault (1980). However, the assemblage cannot be reduced to merely a tool of control, but is also constitutive and productive. The technology of the software seems to bring about a practice (cf. Sørensen 2009) that makes the absence 'non-existent' until the software shows that it exists. As suggested by Sørensen (2009) and Lee (2009), the faith placed in the efficiency and trustworthiness of new technologies makes the question of whether or not the student was actually missing less important than what the materiality of the computer screen showed; the student's absence becomes a verification of the importance of the software to be able to observe school absence while the software becomes a producer of the student's absence.

In the assemblage a productive desire seemed to be at play between transnational discourses about the efficient school, Swedish educational and political discourses on order and control, the teacher's connections with the computer screen, and the red field. It is a productive desire (Deleuze and Guattari 1987, 1983) that makes 
the teacher wish for a better' school with fewer red fields, a productive desire that actually produces a 'better' school in the act of removing the red field and making it yellow. The teacher's wish to get rid of the red field in order to maintain her position as a teacher whose lessons are well attended and to maintain the school's good reputation does not work as a productive force in changing the colors on the boy's page. Within these two examples it can be claimed that different, even contradictory, desires are at play. Sørensen (2009) describes how order is often constructed as social or collective, while disorder is ascribed to the individual. One way of understanding the different desires at play is to claim that the student who usually follows the rules (i.e., is present at the lessons and gets few or no red fields) are regarded as doing so as a result of the social and collective order at the school. Her page thus becomes representative of not only herself, but also of the school and the collective work against absence at the school. The student who is not following the rules becomes representative only of himself. The treatment of the red fields can in this case be described as connected to a predetermined notion of what school absence is: mainly a problem related to the individual student and not to the school or the educational setting. These red fields can be described as easier to handle - or even ignorable - since they are viewed as less related to the educational setting. Even though the analysis in the paper has shown how disorder can never be viewed as detached or individualistic but is always entangled and produced in connections within the assemblage, these common sense understandings of order and disorder could be one way of analyzing the different handlings of the fields.

My meeting with the software, the teacher and the students enables questions that have interesting implications for educational practices, implications which extend beyond the question of how school absences are to be handled. As has been shown, the two students' possibilities of influencing what was recorded on their screens were not 
solely due to their bodily presence when the event took place. This enables a new understanding of what the influence of students may mean: it is not only dependent on their opportunity or ability to talk to their teachers about their absence or other issues, but also dependent on the assemblage in which they take part, in which (gendered) discourses are active. This implies that those who are able to connect themselves to the right components in the school setting, and in this way be able to avoid red fields, may be presented various possibilities. Getting to the classroom on time; bringing the right material; sitting quietly with your jacket, hoodie or backpack off; and getting your green field on the computer screen can be described as forms of self-management. But it is worth noting that, at the same time, the green fields on the computer screen can be theorized as something that opens up the assemblage and makes ruptures possible. On the occasions when the students are in the classroom, the assemblage enables a potential in which the regulations on absence can be challenged; a green field on the computer screen can allow for an absence in class (Jonasson 2011), where students are physically present but not engaged in the lesson (e.g., ignoring the teacher's introduction to the task or silently checking their mobile phones under the table).

What happened, or did not happen, to the students' absences during my visit are interwoven with the mass of materialdiscursive components, components that make an absence appear - or even disappear - in different ways. Seeing red on a computer screen can denote fear of, anger at, or trouble with a student's absence or absences from class. But seeing red can also mean reconsidering school absence and to actually see the materialities of the educational setting - to see red - as a part of how school absence is produced. 
Acknowledgments: I wish to thank the editors and authors of this special issue for productive comments on earlier versions of the paper as well as the two anonymous reviewers for their constructive remarks. I am grateful for the opportunity to discuss the paper with Eva Reimers, Ann-Marie Markström and Hillevi Lenz Taguchi, as well as Magnus Dahlstedt and Anna Bylund. Finally I wish to thank Constance Ellwood for a rigorous proofreading. 


\section{References}

Åsberg, C.; M. Hultman, and Francis, L. 2012. Posthumanistiska nyckeltexter. Lund: Studentlitteratur.

Åsberg, C.; R. Koobak, and E. Johnson. 2011. Beyond the Humanist Imagination. NORA—Nordic Journal of Feminist and Gender Research19, no. 4: 218-30.

Alaimo, S., and S. Hekman. 2008. Introduction: Emerging Models of Materiality in Feminist Theory. In Material Feminisms, ed. S. Alaimo and S. Hekman, 1-19. Bloomington, IN: Indiana University Press.

Bodén, L. 2013. Frånvaro på skärmen. En studie av digitala system för närvaro- och frånvaroregistrering i den svenska grundskolan. Unpublished working paper.

Badmington, N. (2004). Mapping Posthumanism. Environment and Planning A 36, $1344-1351$.

Barad, K. 2007. Meeting the Universe Halfway: Quantum Physics and the Entanglement of Matter and Meaning. Durham, NC: Duke University Press.

Bennett, J. 2005. The Agency of Assemblages and the North American Blackout. Public Culture 17, no. 3: 445-465.

Björklund, J. and N. Sabuni. 2008-06-12. 110 miljoner till jämställdhet i skolan. Dagens Nyheter.

Claes E.; M. Hooghe, and T. Reeskens. 2009. Truancy as a Contextual and Schoolrelated Problem: a Comparative Multilevel Analysis of Country and School Characteristics on Civic Knowledge Among 14 Year Olds. Educational Studies 35 , no. $2: 123-42$.

Colebrook, C. 2002. Gilles Deleuze. New York: Routledge.

Coole, D. And S, Frost. 2010. New Materialism. Ontology, Agency, and Politics. Durham \& London: Duke University Press. 
Corville-Smith, J.; B.A Ryan; G.R. Adams, and T. Dalicandro. 1998. Distinguishing Absentee Students from Regular Attenders: The Combined Influence of Personal, Family and School Factors. Journal of Youth and Adolescence 27, no. 5: $629-40$.

Currier, D. 2003. Feminist Technological Futures. Deleuze and Body/Technology. Feminist Theory 4, no. 3: 321-38.

Deleuze, G. 1990. Negotiations: 1972-1999. New York: Columbia University Press.

Deleuze, G., and F. Guattari. 1983. Anti-Oedipus. Capitalism and Schizophrenia. Minneapolis: University of Minnesota Press.

Deleuze, G., and F. Guattari. 1987. A Thousand Plateaus. Minneapolis: University of Minnesota Press.

Derefeldt, G.; T. Swartling; U. Berggrund and P. Bodrogi. 2004. Cognitive Color. Color Research \& Application 29, no. 1: 7-19

Dolphijn, R. And I. van der Tuin. 2012. New Materialism: Interviews \& Cartographies. Ann Arbor: Open Humanities Press.

Erikson, L. (2004). Föräldrar och skola. PhD diss., Örebro University.

Foucault, M. 1980. Power/knowledge: selected interviews and other writings 19721977. Brighton: Harvester Press.

Grosz, E. 1994. Volatile bodies: Toward a Corporeal Feminism. Bloomington and Indianapolis: Indiana University Press.

Haraway, D. 1989. Primate Visions. Gender, Race, and Nature in the World of Modern Science. New York \& London: Routledge

Hekman, S. 2008. Constructing the Ballast: An Ontology for Feminism. In Material feminisms, ed. Stacy Alaimo and Susan Hekman, 85-119. Bloomington, IN: Indiana University Press. 
Hekman, S. 2010. The Material of Knowledge. Feminist disclosures. Bloomington, IN: Indiana University Press.

Hird, M.J. 2009. Feminist Engagements with Matter. Feminist Studies 35, no. 2: 32946.

Huck, J. 2011. Truancy Programs: Are the Effects Too Easily Washed Away? Education \& Urban Society 43, no. 4: 499-516.

Hultman, K. 2011. Barn, linjaler och andra aktörer. Posthumanistiska pespektiv på subjektskapande och materialitet i förskola/skola. $\mathrm{PhD}$ diss., Stockholm University.

Hultman, K., and H. Lenz Taguchi. 2010. Challenging Anthropocentric Analysis of Visual Data: A Relational Materialist Methodological Approach to Educational Research. International Journal of Qualitative Studies in Education 23, no.5: $525-542$.

Hutchings, J. 2004. Color in Folklore and Tradition - The Principles. Color Research \& Application. 29, no. 1: 57-66.

Jackson, A.Y., and L.A. Mazzei. 2011. Thinking with Theory in Qualitative Research. Viewing Data Across Multiple Perspectives. London: Routledge.

Jonasson, C. 2011. The Dynamics of Absence Behavior: Interrelations Between Absences from Class and Absences in Class. Educational Research 53, no. 1: $17-32$.

Jones, L.; R. Holmes; C. Macrae, and M. Maclure. 2010. Documenting Classroom Life: How can I Write About what I am Seeing?. Qualitative Research 10, no. 4: 479491.

Jönsson, A. 1990. Skolk i grundskolan. En meta-studie. Pedagogisk-psykologiska problem. Nr 538. Lund: Lärarhögskolan i Malmö, Lunds universitet. 
Kearney, C.A., and A. Bensaheb. 2006. School Absenteeism and School Refusal Behavior: A Review and Suggestions for School-Based Health Professionals. Journal of School Health 76, no. 1: 3-7.

Larsson, J.; A. Löfdahl and H. Pérez Prieto. 2010. Rerouting: Discipline, Assessment and Performativity in Contemporary Swedish Educational Discourse. Education Inquiry 1, no. 3: 177-95.

Lee, F. 2009. Letters and Bytes. Sociotechnical Studies of Distance Education. PhD diss., Linköping University.

Lenz Taguchi, H. 2012. A Diffractive and Deleuzian Approach to Analysing Interview Data. Feminist Theory 13, no. 3: 265-81.

OECD. 2012. Starting Strong III. A Quality Toolbox for Early Childhood Education and Care. Paris: OECD Publishing.

Reid, K. 2006. An Evaluation of the Views of Secondary Staff Towards School Attendance Issues. Oxford Review of Education 32, no. 3: 303-24.

Reid, K. 2008. Behavior and Attendance: The National Picture; a Synopsis. Educational Review 60, no. 4: 333-44.

Reid, K. 2010. Finding strategic solutions to reduce truancy. Research in Education 84, no. 1: $1-18$.

Ringrose, J. 2007. Successful Girls? Complicating Post-Feminist, Neoliberal Discourses of Educational Achievement and Gender Equality. Gender \& Education 19, no 4: 471-489.

Ringrose, J. 2011. Beyond Discourse? Using Deleuze and Guattari’s Schizoanalysis to Explore Affective Assemblages, Heterosexually Striated Space, and Lines of Fight Online and at School. Educational Philosophy and Theory 43, no. 6: 598618. 
Rose, N. 1999. Governing of the Soul: The Shaping of the Private Self. $2^{\text {nd }}$ ed. London: Routledge.

Skelton, C. 2010. Gender and Achievement: Are Girls the "Success Stories" of Restructured Education Systems? Educational Review 62, no. 2: 131-142

Skelton, C., B. Francis, and B. Read, B. 2010. “Brains before 'beauty'?” High achieving girls, school and gender identities. Educational Studies 36, no. 2: 185-94.

Skolverket. 2008. Rätten till utbildning. Om elever som inte går i skolan. Rapport 309. Stockholm: Fritzes.

Sommer, B. 1985. What's Different About Truants? Journal of Youth and Adolescence. 14, no 5: 411-22.

Southwell, N. 2006. Truants on truancy - A badness or a valuable indicator of unmet special educational needs? British Journal of Special Education 33, no. 2: 91-7.

Stockholms stads utbildningsförvaltning [Stockholm Educational Department]. 2009. Anvisningar för registrering av elevers frånvaro. Info: 2009-06-12.

Stockholms stads utbildningsförvaltning [Stockholm Educational Department]. 2011. Utbildningsförvaltningen tjänsteutlåtande. DNR: 11-050/693.

SFS[Swedish statues]. 2010:800. Skollag [Education Act].

SFS[Swedish statues]. 2011:506. Förordning om ändring i skolförordningen (2011:185).

Sutphen, R., Ford, J., \& Flaherty, C. (2010). Truancy Interventions: A Review of the Research Literature. Research on Social Work Practice 20, 161-171.

Sørensen, E. 2009. The Materiality of Learning. Technology and Knowledge in Educational Practices. Cambridge: Cambridge University Press.

Sørensen, E., and P. Triantafillou, eds. 2009. The Politics of Self-Governance. Abingdon: Ashgate Publishing Group. 
Tallberg Broman, I. (2013) Föräldrasamverkan i förändring. In Föräldrar, förskola och skola. Om mångfald, makt och möjligheter, ed. A. Harju and I. TallbergBroman, 25-40. Lund: Studentlitteratur.

Tamboukou, M. 2006. Power, Desire and Emotions in Education: Revisiting the Epistolary Narratives of Three Women in Apartheid South Africa. Gender and Education 18, no. 3: 233-52.

Tamboukou, M. 2008. Machinic Assemblages: Women, Art Education and Space. Discourse: Studies in the Cultural Politics of Education 29, no.3, 359-75.

Tufte, E.R. 1983. The Visual Display of Quantitative Information. $2^{\text {nd }}$ ed. Cheshire: Graphics Press.

Veenstra, R.; S. Lindenberg; F. Tinga, and J. Ormel. 2010. Truancy in late elementary and early secondary education: The influence of social bonds and self-control The TRAILS study. International Journal of Behavioral Development 34, no. 4: $302-10$.

Walkerdine, V. 1998. Counting Girls Out. Girls and Mathematics. London \& Bristol: Falmer Press.

Walkerdine, V., H. Lucey, and J. Melody. 2011. Growing Up Girl Psycho-Social Explorations of Gender and Class. London: Palgrave.

Wedin, A-S. 2007. Lärares arbete och kunskapsbildning. Utmaningar och inviter i den vardagliga praktiken. PhD diss., Linköping University.

Youdell, D. 2011. School Trouble. Identity, Power, and Politics in Education. London \& New York: Routledge. 